\title{
Summary Audit Report on Iessons Iearned from \\ the Superconducting Super Collider Project
}

\section{MASTEP}

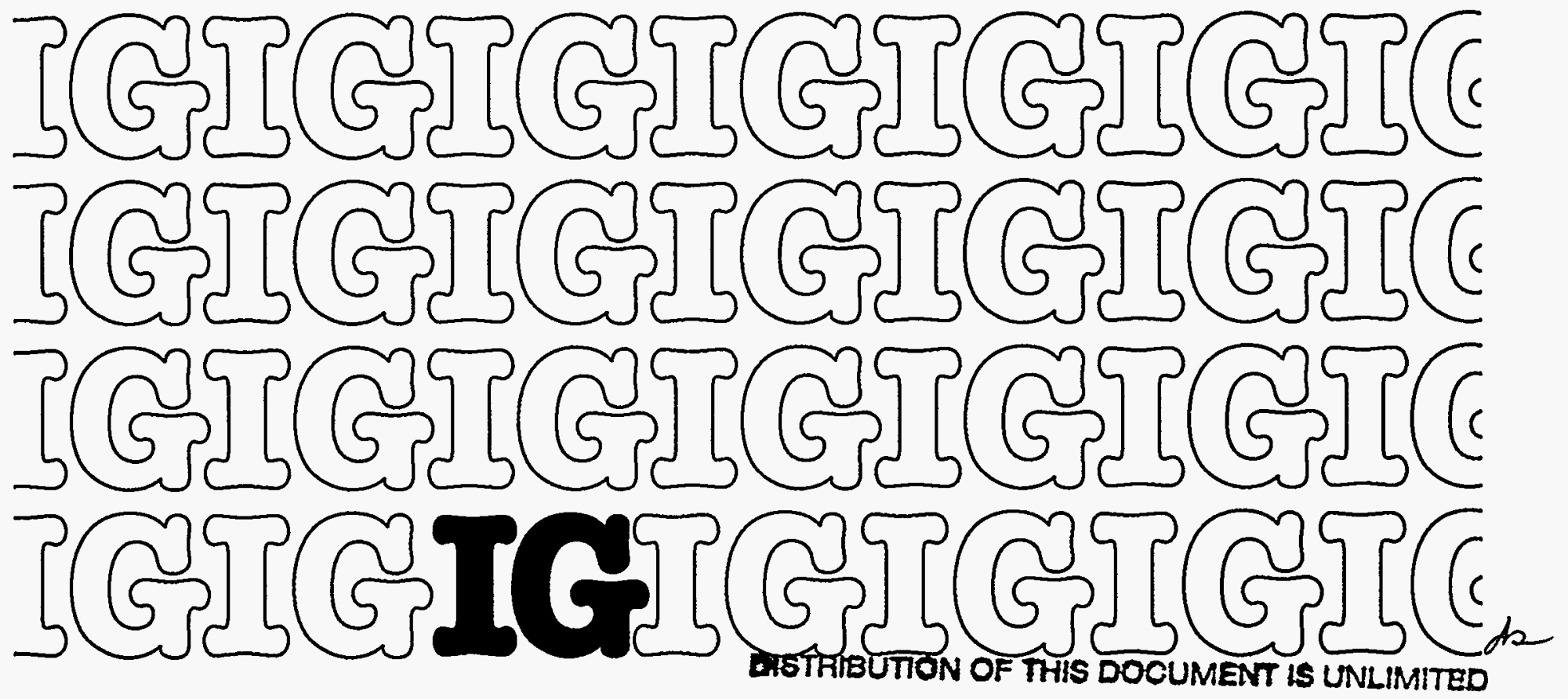


Your comments would be appreciated and can be provided on the Customer Response Form attached to the report.

Appended to this report is a source document that cannot be transmitted electronically due to technological limitations. Therefore, the audit report is not available on the Internet. You may obtain a copy of the report by contacting Wilma Slaughter at (202) 586-1924, or by writing to:

U.S. Department of Energy

Office of Scientific and Technical Information

P.O. Box 62

Oak Ridge, Tennessee 37831 


\section{memorandum}

DATE:

April 23, 1996

REPLY TO

ATTN OF:

IG-1

SUBJECT: $\quad$ INFORMATION: Summary Audit Report on "Lessons Learned From the Superconducting Super Collider Project"

TO:

The Secretary

\section{BACKGROUND:}

In October 1993, the Congress decided to terminate the Superconducting Super Collider (SSC) project after expending about $\$ 1.57$ billion on the project. While both internal and external factors contributed to the demise of the project, its cancellation offers the Department a unique opportunity to analyze what went wrong, correct the mistakes, and apply the lessons learned to future large-scale projects.

\section{DISCUSSION:}

The SSC was to be the world's most powerful particle accelerator. In July 1983, the High Energy Physics Advisory Panel recommended development of the Collider as one of the Nation's highest priorities. In January 1991, the Department submitted the official cost and schedule baseline for the SSC to the Congress. The project was expected to be completed in 1999 at a projected cost of $\$ 8.2$ billion. From 1990 to 1993, the project underwent a series of changes designed to address problems related to the project. After a series of congressional hearings on these matters, the Congress decided to terminate the project on October 28, 1993.

This report discusses several factors that hindered the successful development of the SSC project. These factors relate to project cost estimates, cost and schedule control system, business management systems, the contract instrument, and administration. Specifically, the Department could benefit from improvements to its project cost estimating system by fully utilizing independent cost estimates, and by ensuring that a dependable cost and schedule control system is operational before construction begins. The Department could also benefit from early establishment of funding agreements and appropriate contractor business management systems. An effective contract instrument with commensurate risk apportioned to the contractor, along with adequate Departmental staffing and early involvement with project management will also be of benefit to the future large-scale scientific endeavors of the Department. 
In responding to this report, officials from the Offices of Energy Research and Field Management reviewed the report and provided a joint response. Management agreed in general to apply the lessons learned from the SSC to future projects.

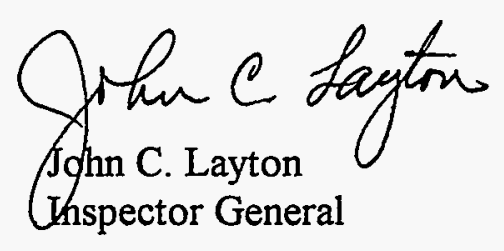

Attachment

cc: Deputy Secretary

Acting Under Secretary .

Director, Office of Energy Research

Associate Deputy Secretary, Office of Field Management

Audit Liaison 


\section{U.S. DEPARTMENT OF ENERGY OFFICE OF INSPECTOR GENERAL}

SUMMARY AUDIT REPORT ON

LESSONS LEARNED FROM THE

SUPERCONDUCTING SUPER COLLIDER PROJECT

Report Number: DOE/IG-0389

Capital Regional Audit Office

Date of Issue: ApriI 23, 1996

Germantown, MD 20874 


\section{SUMMARY AUDIT REPORT ON \\ LESSONS LEARNED FROM THE \\ SUPERCONDUCTING SUPER COLLIDER PROJECT}

\section{TABLE OF CONTENTS}

\section{Page}

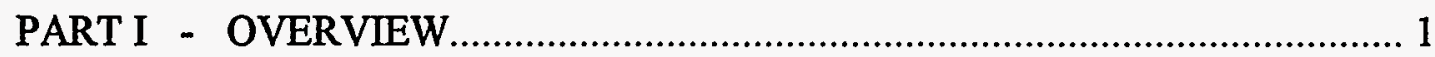

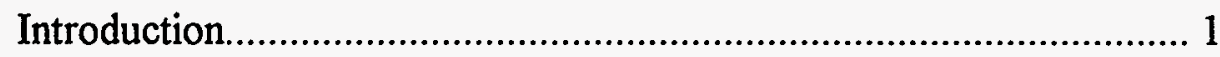

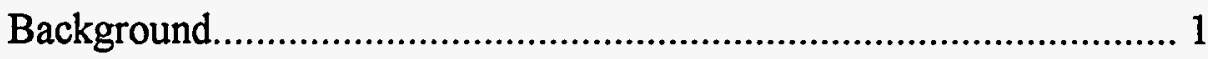

Actions to Consider on Similar Future Projects................................... 2

PART II - DETAILED LESSONS LEARNED FROM THE SSC PROJECT....... 4

Cost Estimates and Cost and Schedule Control System....................... 4

Funding

Business Management Systems.......................................................... 6

Contract Instrument and Administration........................................... 9

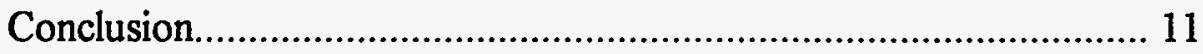

PART III - MANAGEMENT AND AUDITOR COMMENTS........................... 12

PART IV - PRIOR REPORTS ISSUED ON THE SUPERCONDUCTING SUPER COLLIDER ............................................................... 14

APPENDIX - Comments (Memorandum), Office of Energy Research and Office of Field Management. 



\title{
U.S. DEPARTMENT OF ENERGY
}

OFFICE OF INSPECTOR GENERAL

OFFICE OF AUDIT SERVICES

\author{
SUMMARY AUDIT REPORT \\ ON LESSONS LEARNED FROM THE \\ SUPERCONDUCTING SUPER COLLIDER PROJECT
}

Audit Report Number: DOE/IG-0389

\section{$\underline{\text { PART I }}$}

OVERVIEW

\section{INTRODUCTION}

The Superconducting Super Collider (SSC) project was to have been one of the Department's most important and expensive research ventures. In 1989, the estimated cost to complete this project was \$5.9 billion. As of October 1, 1993, the projected cost of the project had increased to between $\$ 11$ billion and $\$ 13$ billion. After expending about $\$ 1.57$ billion, the Congress terminated the SSC project on October 28, 1993.

Both internal and external factors contributed to the demise of this project. Most of the major factors were the subject of numerous reports issued by the Department, the Office of Inspector General, the General Accounting Office, and the Congress. The project's cancellation, however, offers a unique opportunity to analyze what went wrong, correct the mistakes, and apply this knowledge to future large-scale projects.

\section{BACKGROUND}

The SSC was to have been the world's most powerful particle accelerator. A 54-mile racetrack shaped tunnel, using approximately 12,000 superconducting magnets, was designed to focus and guide counter rotating proton beams. The collision of these protons at nearly the speed of light would be recorded on six story, 25-to-50-thousand ton detectors. According to scientists, analyzing these collisions would have advanced scientific knowledge relating to the fundamental components of matter and the laws that underlie all physical processes.

In July 1983, the High Energy Physics Advisory Panel recommended development of the Collider as one of the Nation's highest priorities. Former President Reagan endorsed the project's construction; and in January 1989, Universities Research Association, Inc. (URA) was selected to manage and operate the SSC Laboratory in Waxahachie, Texas. The Department estimated that construction would take 8 years and the onsite construction work force would peak at about 4,500 people. During its proposed 25-year life, the SSC's projected annual operating budget would equate to $\$ 270$ million (in 1988 dollars), and the project was expected to employ about 2,500 scientists, engineers, technicians, and administrative staff.

The Department, in January 1991, submitted the official cost and schedule baseline for the SSC project to the Congress. It was anticipated that the project would be completed in 1999 at a projected cost of $\$ 8.2$ billion. In 1993, the project completion date was extended to 2002 . While an official cost estimate revision had not been completed prior to project termination, unofficial estimates of the project's cost ranged from $\$ 11$ billion to over $\$ 13$ billion. 
The SSC project underwent a series of changes, from 1990 to 1993 , designed to address shortcomings relating to this highly complex project. Despite these changes, project costs escalated and management's ability to deliver the proposed project on time and within budget was questioned. After a series of congressional hearings on these matters, the Congress decided to terminate the project.

\section{ACTIONS TO CONSIDER ON SIMILAR FUTURE PROJECTS}

A number of problems hindered the successful development of the project. The Department needs to consider and address these issues in order to avoid similar problems on future projects of this size and complexity. These problems fall into four categories:

- Cost Estimates and Cost and Schedule Control System

- Funding

- Business Management Systems

- Contract Instrument and Administration

Cost Estimates and Cost and Schedule Control System. The Department should take full advantage of independent cost estimating and include all known project costs in its estimates. In this regard, the total project cost estimate should represent the best possible estimate, and the Department should ensure that a dependable cost and schedule control system that is capable of measuring costs and progress against the estimate is in place before construction begins.

To obtain the best possible benchmark, the Department should include all known components in its cost estimate. In 1990, the Department's independent cost estimators provided Departmental managers with a project cost and schedule estimate of $\$ 11.8$ billion. However, the SSC Office estimated that the project would cost $\$ 8.2$ billion. The Department relied upon the lower contractor estimate, and substantial known costs were not included in the official estimate provided to the Congress. The variance in cost estimates occurred, in part, because of the Department's historical practice of excluding certain costs from accelerator projects -- at one time consistent with Departmental policy - that made it difficult for the Congress to assess the affordability of the project.

Once an estimate has been approved, the Department needs to ensure that a dependable cost and schedule control system is in place and operational before beginning construction. In the case of the SSC project, an effective system was not established. As a result, the Department did not have access to information necessary to measure performance or benchmark costs against the baseline.

Funding. Funding from all sources should also be secured during the early phases of a project. The Department projected that about $\$ 2.6$ billion in contributions for the SSC would be provided by the State of Texas and foreign contributors. However, of the seven countries from which SSC officials sought support, none provided any cash contribution.

Business Management Systems. Appropriate contractor business systems are also crucial to the success of a project. Without adequate systems, the Department has no assurance that the mission and functions assigned to the contractor are properly executed; resources are protected; and financial, statistical, and other reports resulting from these systems are accurate, available, or reliable.

The SSC contractor attempted to implement the required systems; however, as of project termination, accounting, procurement, internal audit, and scientific and technical information management systems had not been brought into alignment with Departmental standards and practices. 
Contract Instrument and Administration. Finally, the Department should ensure that the contract instrument and reporting channels effectively assist in the management of large-scale construction projects. The SSC contract, however, was not fully effective in that it limited the contractor's legal liability. Also, the SSC project was initially understaffed and cut off from the normal administrative and reporting channels. Had the project remained in normal channels, where it would have been subjected to operations office and Headquarters oversight functions, many of the problems encountered during the developmental stages of the project might have been detected and corrected earlier.

Every project faces significant and unique challenges. The adoption of a lessons learned approach to the SSC project provides the Department with an excellent opportunity to learn from this experience and apply the lessons learned to the successful development of future Departmental scientific endeavors. Part II of this report discusses in greater detail the challenges faced by the Department in the management of the SSC project.

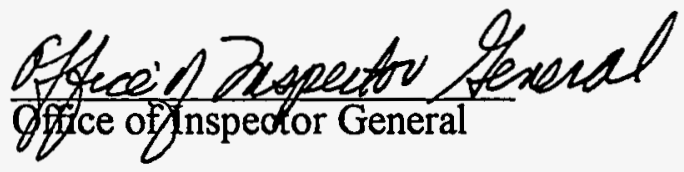




\section{PART II \\ DETAILED LESSONS LEARNED FROM THE SUPERCONDUCTING SUPER COLLIDER PROJECT}

Based on a review of the history of the SSC project, the Department of Energy (DOE) has an opportunity to examine and possibly strengthen its system of project management. An effective project management system should ensure that: (1) a project's cost estimate represents the best possible estimate; (2) a dependable cost and schedule control system is in place and capable of measuring costs and progress against the baseline; (3) funding from all sources is secured before the initiation of a project; (4) appropriate contractor business systems are established, and (5) the contract instrument and reporting channels effectively assist in the administration of large-scale projects. Problems in each of these areas hindered the successful development of the SSC project.

\section{COST ESTIMATES AND COST AND SCHEDULE CONTROL SYSTEM}

A project cost estimate should represent the best possible estimate and include all known costs. A dependable cost and schedule control system should also be in place to assist management in the measurement of progress against the baseline. The SSC's cost estimate did not include all known costs, and costs continued to increase over the 4-year life span of the project. In 1989, the Department informed the Congress that the total project would cost $\$ 5.9$ billion. The Department's official estimate increased to $\$ 8.2$ billion in 1991 . At project termination, unofficial estimates of the total cost of the project ranged between $\$ 11$ billion and $\$ 13$ billion. Further, during this period, an effective cost and schedule control system was not in place, and escalating costs were not immediately visible to management.

\section{Cost Estimates}

Realistic project cost estimates allow senior Departmental officials and the Congress to assess the affordability of a project. Although the Department is reported to have spent approximately $\$ 100$ million to research, design, and price the SSC, the project's estimated cost continued to increase.

In Fiscal Year 1989, the Department projected it would need $\$ 5.9$ billion to complete the project. However, even as the Congress was debating the project's affordability, the SSC Laboratory was recommending major changes in the collider system's design. For example, the SSC Laboratory recommended that the High Energy Booster be doubled from 1 trillion to 2 trillion electron volts; the collider ring circumference be changed from 52 to 54 miles; and the aperture be increased for the dipole magnets. Three panels reviewed the cost of these changes: a sub-panel of the High Energy Physics Advisory panel, a DOE Office of Energy Research Review Committee, and DOE's independent cost estimating staff. These reviews resulted in cost estimates that ranged from $\$ 8.4$ billion to $\$ 11.8$ billion. The Department in January 1991 , however, informed the Congress that the project would cost $\$ 8.2$ billion, an amount lower than the projections of the three independent review panels.

The Department generally relied on SSC Laboratory estimates that were lower than independent estimates. For example, as early as 1988, the Congressional Budget Office, based on the Department's historical cost performance, estimated that the cost for construction activities alone would be $\$ 6.4$ billion. The Laboratory estimated that combined construction and pre-operating costs would be between $\$ 3.9$ billion and $\$ 4.8$ billion. Laboratory and independent cost estimates also differed substantially for magnet costs, detector costs, contingency, escalation, pre-operation costs, prior years' costs and anticipated costs due to schedule delays. 
The Department's independent cost estimating staff expressed the belief that the Laboratory's estimates were both unrealistic and unachievable.

The difference between independent estimates and the Department's estimate was due, in part, to the Department's practice of excluding certain costs from accelerator estimates. In February 1993, the General Accounting Office (GAO) reported that the Department's estimate excluded about $\$ 1.2$ billion in known costs such as $\$ 500$ million for detectors, $\$ 400$ million for Laboratory pre-operations, $\$ 118$ million for DOE program direction, about $\$ 60$ million for land costs, and \$125 million for infrastructure and general support. The GAO concluded that the Laboratory and the Department had obscured the complete cost of the project by excluding these components from the total cost estimate. The Department has since modified its approach to accumulating total project costs.

\section{Cost and Schedule Control System}

An appropriately designed and operational cost and schedule control system provides the tools necessary to measure contractor performance against goals, objectives, and baseline cost estimates. Although the SSC contractor attempted to develop and implement a cost and schedule control system, full implementation never took place. As a result, the Department did not have access to information necessary for effective measurement and benchmarking of work, costs, and schedules.

The absence of a fully implemented cost and schedule control system (and contractor practices) concealed substantial cost overruns on the project. The following four examples illustrate contractor activities that could have been highlighted through implementation of an effective cost and schedule control system.

- Almost 1 year after $\$ 22$ million in project changes were approved, the contractor had not recorded these changes against the baseline. Further, approved cost increases and changes to the $\$ 8.2$ billion cost estimate were not recorded against the baseline control log.

- The conventional construction subcontractor retroactively changed the baseline cost and schedule control reports. For example, reports were changed to indicate that the conventional construction program was not behind schedule or over budget when, only a month previously, these reports showed that the project was $\$ 28.1$ million ahead of scheduled expenditures and $\$ 47.6$ million over budget.

- The Industrial Access and the East Complex connector roads were completed or under construction before the formal changes to undertake the work were approved.

- Construction costs were shifted from the conventional construction accounts to internal SSC Laboratory division accounts. For example, construction costs, normally charged to the Conventional Construction Division, were charged to Laboratory Technical Services accounts for alterations to conventional facilities. This practice allowed the contractor to understate the true costs of conventional construction.

Establishment of an effective cost and control system could have brought some of these issues early on to the Department's attention. 


\section{FUNDING}

Funding arrangements should also be established during the initial stages of a project. The SSC project was predicated upon the receipt of substantial funding from foreign sources. The Office of Management and Budget expected that $\$ 1.8$ billion of the $\$ 5.9$ billion estimate would be obtained from non-Federal sources. Although specific goals were not set, the Department anticipated that about $\$ 900$ million would be contributed by the State of Texas with the remainder being contributed by foreign countries. The State of Texas provided the requested funding. However, of the seven countries from which SSC officials sought support, none provided any cash contribution.

\section{Foreign Country Contributions}

The Department was unable to obtain projected contributions (cash, in-kind equipment, services, etc.) from foreign countries because (1) Japan was uncertain of U.S. Congressional support for the project; (2) European countries had made commitments to the European high energy accelerator; and (3) the financial ability of some countries to contribute to the project was overestimated.

Japan was requested to provide the majority of foreign contributions. Japanese contributions, however, hinged on broad support for the SSC project. A key for continued congressional support was the Department's ability to obtain foreign contributions. When no other foreign resources were obtained, congressional support decreased; and Japan chose to defer making any contributions.

Expected contributions from European countries did not take into account the latter's commitment to the proposed European high energy accelerator. Further, some countries were apparently unaware of the contributions expected from them. For example, the Chairman of the United Kingdom (UK) Science and Engineering Research Council stated that there had been no commitment from the UK to spend any money on the SSC project. He emphasized that if the UK did have the expected $\$ 15$ million contribution, it would have been spent on the planned European particle accelerator.

Other foreign countries did not have the funds available in their budgets to make the projected contributions. The $\$ 25$ million contribution projected from Canada was more than that country's entire annual budget for high energy physics. Also, an official from France stated that the French government would have had to triple its research budget in order to provide any money at all.

The Department did make a concerted effort to secure foreign contributions. In 1988, the then Secretary of Energy sent formal invitations to his six counterparts within the economic summit countries to participate in the SSC project. Also, high-level Departmental delegations visited Europe, Japan, and South Korea to discuss potential interest in the project. However, these efforts were unsuccessful, and as a result, the future success of the project was put in jeopardy.

\section{BUSINESS MANAGEMENT SYSTEMS}

Projects the size and complexity of the SSC also require the establishment of appropriate contractor business management systems. The Department awarded the SSC management and operating contract and proceeded with the project without assurance that the contractor had in place effective and operational systems. 
The Department of Energy Acquisition Regulation requires that the awardee have business management systems that are documented and acceptable. Business management systems include, but are not limited to accounting, procurement, internal audit, and scientific and technical information management systems. These systems provide assurance that the mission and functions assigned to the contractor are properly executed; resources are protected; transactions are properly recorded; and financial, statistical, and other reports resulting from these systems are accurate, available, and reliable.

As late as project termination, the contractor's accounting system had not been formally approved by the Department, and its procurement system did not fully comply with Departmental regulations. Other management systems encountered start up difficulties or did not meet applicable Departmental standards. Financial data was not accurately integrated into the Department's Financial Information System (FIS); the required internal audit function was not appropriately staffed and lacked independence; and a system for the management of scientific and technical information products was not fully implemented.

Financial Management and Accounting System

The Department accepts a contractor's customary accounting practices if they conform to generally accepted accounting principles, produce equitable results, are consistently applied, and are not in conflict with the Department's Acquisition Regulation. Despite this requirement, the SSC's accounting system was never formally approved by the Department, and inaccurate financial information was entered into the FIS. As a consequence, the Department did not have a satisfactory basis to assess the financial status of the project or to determine whether the contractor charged only allowable costs to the contract.

The Department's FIS automatically integrates the results of all major management and operating contractor activities into one system. This allows the Department to track and control budgeted programs and to issue timely financial reports to program managers on contract activities. For the SSC project, it took almost 3 years--from January 1989 to September 1991-for the contractor to integrate its accounting system into the Department's FIS. This lack of integration required manual entry of data and created reconciliation problems in Fiscal Years 1993 and 1994. For example, the SSC Laboratory's statements of Voucher Accounting for Net Expenditures Accrued (VANEA) differed from the contractor's records for Fiscal Years 1993 and 1994 by $\$ 35.8$ million and $\$ 12.4$ million, respectively.

In addition, the contractor did not have an adequate system to prevent the occurrence of questioned costs. In July 1993, the Department's Project Management Compliance System Review reported that the contractor's accounting system had not been given formal approval. Of the 30 policies in the contractor's accounting policies and procedures manual, only 14 were approved by the Department. Of the remainder, 9 were under review and 7 were still under development. The OIG, in several reports, questioned $\$ 207$ million in costs incurred by the contractor. If the contractor had an effective and approved accounting system in place, some of these questioned costs may have been addressed at an earlier date.

\section{Procurement System}

The Department's Acquisition Regulation requires contractors to develop and implement appropriate procurement systems. These systems should promote the overall mission of the activity and encourage competitive subcontracting. In this regard, all subcontractors should be treated fairly, solicitation documents should clearly describe contract requirements, approvals should be obtained from the Department when certain dollar thresholds are exceeded, and contract files should clearly document the basis on which subcontracts are awarded. 
The Department utilizes Contractor Purchasing System Reviews to determine if a contractor's procurement system is in compliance with the Department of Energy Acquisition Regulation. In 1991, a Departmental review of the SSC's procurement system found that prescribed procedures were not being consistently followed, and additional policies and procedures were needed to strengthen internal controls over the procurement system. Additionally, OIG reviews found that the contractor issued vague Memorandum Purchase Orders (MPOs), conducted questionable procurement activities, and performed less than effective subcontract administration.

One of the deficiencies noted was that the SSC Laboratory entered into agreements with other Departmental laboratories using MPOs to obtain services, equipment, or materials. This type of procurement instrument did not require the recipient of the funds to provide detailed information on how the project funds were spent. In one case, the only description on a $\$ 1.2$ million invoice was the statement: "SSCL.-MO R\&D Costs." In addition, funding ceilings for MPOs were substantially increased without any apparent change in the scope of the work. The Department's Inspector General reported in October 1993 that funding for six MPOs had increased by a total of $\$ 36.1$ million without any explanation.

Consulting services were also acquired inappropriately. According to a report issued by the contractor's internal audit staff, consultants were brought in to explore ways to have an unnamed Japanese multi-national corporation contribute between $\$ 500$ million and $\$ 1.5$ billion. The consultants expected a fee of $\$ 15$ million to $\$ 20$ million for a $\$ 1$ billion contribution. This procurement violated 11 prime contract and SSC Laboratory policy requirements. Yet, the consultants were awarded a 30 -day contract at $\$ 1,000$ a day, plus $\$ 19,990$ in expenses and ultimately collected $\$ 38,298$ before the contract was canceled.

Subcontract administration problems also occurred during project termination. The Department was required to determine whether each settlement with a subcontractor had been arrived at in good faith, was reasonable in the amount, and was allocable to the terminated portion of the subcontract. However, the SSC Laboratory did not have readily available information that quantified the number of subcontracts that had been entered into or the amount that had been expended on these subcontracts. Without this information, the Department was unable to determine its total liability for the SSC project or plan for close-out audits on subcontracts.

\section{Internal Audit}

Internal audit is another integral component of both the Department and its contractors internal control structure and serves to provide assurance that best business practices are being followed. As such, management and operating contracts awarded by the Department incorporate appropriate clauses calling for the establishment of an internal audit function.

The SSC's internal audit function did not meet Departmental requirements because it was not appropriately staffed and organizationally independent. Until 1992, the audit manager was the only internal auditor. Further, the audit function was not independent of the day to day operations of the project. To be considered organizationally independent, the contractor's internal audit group must report to the head or deputy head of the organization. However, the SSC internal audit manager reported to the head of the legal department, a staff position. This situation was not corrected until 1992 when additional staff was assigned to the internal audit organization, and the audit manager began reporting to the Laboratory director. Without an effective internal audit function, the contractor did not have a comprehensive system to identify and correct problems internally. 
Technical Information

Another key business management function is the collection of scientific and technical information. The Department's Guide to the Management of Scientific and Technical Information states that "scientific and technical information products are often the only demonstrable results of Departmentally funded work, [and that] the value of these products is not only in the quality of the work but also in their timely availability to the various interested audiences." The SSC's project termination plan required that the contractor collect all technical documents and ensure they be accessible at a Federal record center under a pre-termination work breakdown structure indexing system.

As of February 1995, the Laboratory did not have an adequate system to collect, summarize, and preserve scientific and technical information. Approximately, 67 percent of the 83,000 technical documents collected following project termination had not been indexed. Furthermore, the Department's Office of Scientific and Technical Information had not received about 21 percent of the required scientific and technical products generated by the contractor. The contractor was unable to identify the universe of information that should have been provided to the Federal record center. During Fiscal Year 1995, the contractor attempted to rectify these problems. Discussions with the project office officials indicated that the documents were being indexed and discrepancies relating to its scientific and technical products had been reconciled.

\section{CONTRACT INSTRUMENT AND ADMINISTRATION}

The contract instrument and administrative and reporting channels should also aid management in the administration of large-scale construction projects. Contract deviations, an extremely limited Departmental presence at the SSC Laboratory, and a reporting network that bypassed the normal reporting chain limited the Department's ability to manage the SSC project.

\section{Contract Deviations}

A November 1990 "Special Report on the Department of Energy's Superconducting Super Collider Program" identified several SSC contract clauses that deviated from standard provisions utilized by the Department to administer contracts. According to the report, the Department's contract for the SSC Laboratory had 89 operative clauses, 25 of which either deviated from the standard clauses or were special clauses not contained in the Department's Acquisition Regulation.

Two of the deviations limited the contractor's liability. The contract clauses on Fines and Penalties and Risk of Loss of Government Property shifted responsibilities for any willful misconduct on the part of the contractor's staff to the Government. Additionally, the Fines and Penalties clause omitted the traditional reference to contractor supervisory representatives. The applicable subclause limited the contractor's liability to the:

... willful misconduct or lack of good faith on the part of any of the Contractor's trustees, overseers, or corporate officers, or the Laboratory Director or Deputy Director.

Deletion of "supervisory representatives" from the contract language significantly increased the risk to the Government and minimized the contractor's risk.

The subclause on the Risk of Loss of Government Property also limited the contractor's liability. Managerial personnel other than top corporate officials were excluded from the willful 
misconduct and lack of good faith standard. The standard contract subclause holds a contractor liable and financially responsible for managerial personnel actions based on willful misconduct or lack of good faith. However, in the SSC contract, the contractor's liability was confined only to the willful misconduct or lack of good faith on the part of senior corporate executives.

\section{Departmental Presence}

The absence of an adequate Departmental presence and the inability to recruit qualified individuals to administer the SSC contract allowed the SSC project to operate for 2 years without a stable leadership structure. For example, key Departmental vacancies on the SSC Laboratory project were not filled as of April 1991. Further, insufficient staff at DOE Headquarters resulted in almost complete reliance on the contractor to make key program decisions.

Three different reviews reported that the Department's staffing was not adequate and highlighted a high turnover rate in key positions. As of March 1990, while contractors had about 500 employees at the Texas site, only one Federal staff member from the Office of the SSC Laboratory and six support personnel from the Chicago Operations Office were permanently assigned there. The key positions of program manager at Headquarters and Department project manager and division chiefs in Texas were vacant. The Department did not name a project manager until May 1990. The short tenure of the Department's staff also contributed to frequent changes of direction, little long-term operational planning, and diminished Departmental accountability.

\section{$\underline{\text { SSC Project Reporting Structure }}$}

Another deterrent to the successful management of the SSC project was the removal of the project from the Department's established administration and reporting channels. In most instances, a project under the auspices of the Department's High Energy Physics program would report to a Departmental operations office and Headquarters Office of Energy Research. Because the SSC was considered a major undertaking and due to concern that Headquarters could not act on a real-time basis, a reporting structure was created, wherein the SSC project director reported directly to the Secretary. This structure removed the project from the established administrative and reporting channels involving the operations office and Headquarters programmatic and administrative functions.

The unique reporting structure created confusion and caused delays in reviewing and assessing the contractor's systems. For example, a memorandum of understanding between the Chicago Operations Office and the SSC Project Office split the accounting responsibility for the project between the two offices. Chicago was of the opinion that it was not responsible for performing the cyclical reviews and annual certification called for in DOE Order 2200.13, "Oversight of Integrated Contractor Financial Management," because this matter was not addressed in the memorandum of understanding. The project office did not perform these reviews because the Order required that the reviews be performed by the activity's Chief Financial Officer.

It was not until 1993--4 years into the project--that the Department performed routine reviews of contractor's systems. These reviews identified deficiencies in contractor performance that could have been remedied at a much earlier time. In the future, the Department needs to clarify organizational responsibilities and rely on existing mechanisms to ensure that major scientific endeavors of this type are successful. 


\section{CONCLUSION}

The Superconducting Super Collider project's cancellation offers the Department a unique opportunity to analyze what went wrong, correct mistakes, and apply this knowledge to future large-scale projects. In providing this report, we believe that consideration of the issues discussed above will enable the Department to avoid similar problems on future projects. Part III of this report contains a synopsis of management comments and auditor comments. Management comments in their entirety are included in Appendix I to this report. A listing of prior reports issued on the SSC project is included in Part IV of this report. 


\section{$\underline{\text { PART III }}$}

\section{MANAGEMENT AND AUDITOR COMMENTS}

In responding to this report, officials from the Office of Energy Research and the Office of Field Management reviewed a draft of this report and provided a combined response. In general, management agreed with many of the suggestions to apply the lessons learned from the SSC to future projects. However, management indicated that the report did not present a complete picture. A summarization of management and auditor comments follow. Management's comments are included in their entirety in the Appendix to this report.

Management Comments. Management attributed much of the real increase in the SSC cost estimate to slippages in the project schedule forced by funding profiles being stretched out by the Congress and later by the Executive Branch. They also agreed that their total project cost estimate did not contain all costs associated with the project and that rapid changes in technology and the scientific subject matter made it difficult to determine the costs of scientific instruments. In addition, management indicated that the Department has since taken actions to ensure that cost estimates include all known costs. For similar future scientific projects, management suggested that a phased approach to baselining the cost estimates may be appropriate.

Management stated that a dependable cost and schedule control system should be in place early in the construction process, and that the lack of an adequate cost and schedule control system hampered effective project management. Such a system however, in management's opinion, would not have prevented major cost increases in the SSC project. Management further commented that although it would be desirable to obtain firm commitments for funding before the initiation of a project, this may not be realistic. They stated that requiring foreign commitments before starting a project would effectively give foreign powers a veto over the project. Nonfederal sources are unlikely to make commitments without the support and approval of the Congress. Also, management agreed that effective business management systems are clearly needed, but did not agree that they needed to be established prior to project initiation.

Management also noted that the Department's management and operating contracts have been changed as a part of its Contract Reform Initiative. However, management's response emphasized that the contract clauses did not result in significant problems for the SSC.

In commenting on the SSC management structure, management agreed that the removal of the project from established administration and reporting channels did disrupt the usual oversight of the project and that many of the problems usually corrected through that process were allowed to fester. In the case of the SSC, standard Office of Energy Research reviews did not happen, and the Department was severely hampered in its ability to respond credibly to allegations of mismanagement and project cost overruns.

Management, in conclusion, noted that a balanced approach will be important in applying the lessons learned from the SSC to future projects and stated that developing a cooperative team spirit is needed to get the job done effectively, rather than adding additional layers of staff, systems, and regulations.

Auditor Comments. As discussed in the report, the Department has a responsibility to establish an effective project management system to ensure the future success of projects similar to the SSC. Strengthening cost estimates, cost and schedule control systems, business management systems, and contract administration will greatly enhance the success of future Departmental initiatives. 
A basic requirement for project management is the establishment of a total project cost estimate. The original estimate for the SSC was about $\$ 5.9$ billion. Subsequent design changes to the size of the accelerator, magnet apertures and intense foreign interest to expand the scope of the detectors accounted for a $\$ 2.3$ billion dollar increase in the project. In 1993, the Department's Baseline Validation Review Committee identified \$1.2 billion in related known costs that were not included in the original estimate and another $\$ 1.5$ billion in cost risks beyond the original baseline that could occur if no efforts were made to manage these risks. Only $\$ 2$ billion was attributable to the funding profile being stretched out by the Congress and later the Executive Branch. Therefore, it is imperative that the Department develop a realistic total project cost estimate upfront and monitor progress against that baseline throughout the life of the project.

Also, funding from all sources should be secured before the initiation of a project. The Congress's approval of the SSC project was based on the Department's ability to obtain about one-third of project funding from non-federal sources. The Department was successful in obtaining a commitment of $\$ 900$ million from the State of Texas, but was unable to obtain firm commitments from foreign participants. Departmental management overestimated the availability of funding from foreign participants. In other projects, such as the European high energy accelerator, multi-national participation has been successful.

Appropriate business management systems also need to be established early on to promote the successful completion of a project. Traditionally, when the Department solicits proposals for a management and operating contract, it ensures itself that the contractor has business systems in place that will provide the Department with sufficient and reliable data to monitor the contract. Business systems historically include the procurement, accounting, financial, internal audit, and scientific and technical information systems. Ineffective systems create the perception of mismanagement. An effective system would have provided the data necessary to handle many of the challenges faced by the Department in the management of the SSC project.

Further, appropriate contract mechanisms are needed to effectively manage a project. In the case of the SSC project, contract deviations limited the contractor's liability and placed the burden on the Department. The actions proposed by the Contract Reform team, and cited by management in its response, should strengthen the Department's contractual relationship with its contractors.

In conclusion, an effective project management system is of paramount importance to the success of future Departmental projects. Management has an opportunity to adopt a lessons learned approach on the SSC project to avoid similar pitfalls on future endeavors. Good business practices dictate that management have at its disposal appropriate contractor systems, adopt best business practices, and apply good historical data from prior projects to ongoing and future scientific endeavors. 


\section{PART IV}

\section{PRIOR REPORTS ON THE SUPERCONDUCTING SUPER COLLIDER LABORATORY}

Listed below are reports related to the SSC project issued by the Department, Office of Inspector General, the General Accounting Office, and the Congress. This listing is not all inclusive, but reflects the major sources utilized in this report.

\section{Departmental Reports}

Report of the DOE Compliance Review Team on SSC Laboratory Project Management Control System, July 1993, U.S. Department of Energy, Office of Energy Research, Superconducting Super Collider Project Office

Report of DOE Review Committee on the Baseline Validation of the Superconducting Super Collider, August 1993, U.S. Department of Energy, Office of Field Management (for the Office of Energy Research)

Office of Inspector General Reports

Report \# Date Issued

DOE/IG-0291 November 16, 1990

DOE/IG-0305 March 20, 1992

DOE/IG-0313 July 7, 1992

DOE/IG-0324 April 14, 1993

DOE/IG-0336 October 22, 1993

MA-02

CR-MA-94-01 December 10, 1993

CR-MA-94-02 December 9, 1993

CR-MA-94-03 July 15, 1994

CR-MA-95-01 October 14, 1994

CR-MA-95-02 February 10, 1995

CR-MA-95-03 May 31, 1995

\section{Subject of Report}

Special Report on the Department of Energy's SSC Program

Follow-up Audit of the Department of Energy's SSC Program

The Department of Energy's SSC Conventional Construction Program

SSC Laboratory Small Business Program

Controls Over Superconducting Super Collider Subcontractor Expenditures

Review of Internal Controls at the Superconducting Super Collider

Physical Security

Subcontract Information

Controls Over Payroll

Prohibited Expenditure

Documentation \& Technical Closeout Activities

URA's Administration of EG\&G Subcontract 


$\begin{array}{lll}\text { CR-C-93-01 } & \text { June 17, 1993 } & \text { SSC Incurred Cost Audit 1989-1991 } \\ \text { CR-C-95-01 } & \text { February 3, 1995 } & \text { SSC Laboratory Incurred Cost Audit 1989 } \\ \text { CR-V-93-01 } & \text { February 26, 1993 } & \text { FY 1992 VANEA } \\ \text { CR-L-94-03 } & \text { November 2, 1993 } & \text { FY 1993 Federal Managers' Financial Integrity Act } \\ \text { CR-V-94-05 } & \text { April 28, 1994 } & \text { FY 1993 VANEA } \\ \text { CR-V-95-03 } & \text { April 21, 1995 } & \text { FY 1994 VANEA } \\ \text { CR-V-95-10 } & \text { January 9, 1995 } & \begin{array}{l}\text { 1995 Assessment of the Internal Audit Function at } \\ \text { the Superconducting Super Collider Laboratory }\end{array}\end{array}$

\section{Congressional Testimony and Report}

Mismanagement of DOE's Super Collider, Hearing Before The Subcommittee on Oversight and Investigations of the Committee on Energy and Commerce, House of Representatives, June 30, 1993, Serial No. 103-76

Out of Control...:A Staff Report, for the Subcommittee on Oversight and Investigations, Committee on Energy and Commerce, U.S. House of Representatives, December 1994

\section{U.S. General Accounting Office Reports}

Report \#

GAO/RCED-86-79

GAO/RCED-89-18 January 1989

GAO/RCED-90-33BR October 1989

GAO/RCED-91-94FS February 1991

GAO/RCED-91-116 April 1991

GAO/RCED-92-242 July 1992

GAO/RCED-93-75 December 1992

GAO/RCED-93-87 February 1993

\section{Subject of Report}

Information on DOE Accelerators Should Be Better Disclosed in the Budget

DOE's Super Collider

Information on Site Selection Process for DOE's Super Collider

Super Collider Estimates and Germany's Industrially Produced Magnets

Status of DOE's Superconducting

Super Collider

Implementation of the Super Collider's Cost and Schedule Control System

Foreign Contributions to the Superconducting Super Collider Super Collider Is Over Budget and Behind
Schedule 


\section{memorandum}

DATE: Marcr: 4, 1990

hepLY ro Energy Research

ATTN OF:

subsect: Comments on Summary Audit Report on Lessons Leamed From the Supercanducting Super Collider Project

To: Gregory Friedman, Deputy Inspector General for Audit Services

Thank you for the opportunity to review and comment on the Iritiar Draft Report on "Lessons Learned From the Superconducting Super Collider Project." Because both the Office of Energy Research and the Office of Fleld Management were directly involved in the Superconducting Super Collider (SSC) Project, we have combined our comments into one consolidated response. Our comments, which we understand will be included in the final report, are provided below.

In general, we agree with many of the recommendations made in this report by the Office of the Inspector General (IG). The report is usefill in puiling together several of the lessons identified in earlier audits. Because of its focus on areas previously reviewed by the IG, however, this report does not present a complete picture.

Many of the issues are highly complex and difficult to convey in a report of this type. For instance, while first cla'ss management systems are essential to any well nun project, much of the real increase in the SSC cost estimate cited in the report resulted from the slippage in the project. schedule forced by funding profiles being stretẹed out by the Congress and later by the Executive Branch. These changes in funding levels made planning difficult, leading to inefficiencies, as well as apparent cost increases due to inflation. A substantial increase resulted from a dexision to slip the SSC completion date from 1999 to 2002.

The Baseline cost estimate was carefully considered, but some of the estimates quoted by the present report are not. Saying that "unofficial estimates ranged from $\$ 11$ billion to over $\$ 13$ billion" gives credence to questionable and casual estimates; it weakens the credibility of the report. While there was not time to complete a revised cost and schedule baseline reflecting the now schedule prior to project termination, the best estimate available of the magnitude of that increase is contained in a letter from Secretary OLeary to Chaiman John Dingell of October 18, 1993. The letter states that, "On the basis of information cirrently available, it is my expectation that these management actions will allow us to complete the SSC in the year 2002 for less than $\$ 11$ billion in as-spent dollars." 
Unfortunately, control of such cost increases is outside the domain of control of auditing and management systems. Clearly, a dependable cost and schedule contral system should be in place early in the construction process, and the lack of an adequate cost and schedule control syatem hampered effective project management. Such a system, however, would not have prevented the major cost increases in the SSC project.

Another critical issue which the report mentions, but does not give gufficient emphasis, is the impact of the SSC management structure. While "the Ietroval of the project from the Departotent's established administration and reporting chamels" had many: day-to-day benefrts, it did disnupt the usral oversight of the project and many of the problems normaily corrected. through that process were allowed to fester. Problems with business and managerrient systems in particular are usually identified earty in a project by standard Department reviews, and subsequently corrected before they can have a significant impact. In the case of the \$SC, the standard Office of Energy Research neviews did not happen, and the Department pras severely hampered in its ahility to respond credibly to allegations of mismanagement arid project cost avernins.

Although effective Business Management Systems are clearly needed, it is not claar that they need to be "in place and functioming before inifiating large scale projects." We agree, however, that they must be in place early in the project, and that the SSC:project was generally defivient in this respect. Although this contributed to the pefeeption of mismanagement the statiement that "the Department had no assurance" regarding proper management of the project is far too strong. While deficient, reporting did take place and was supplemented by day-today interactions between the laboratory and DOE Project Office.

As noted in the report, the method the Bepartment used in compiling its estimate of Total Project Costs for accelerator projects did, in fact, not include certain costs associsted with the project. It should be noted; however, that in presenting SSC costs and finding profiles the Department was carefill to list the assumptions made (such as the finding profile and which yea: dollars were assumed). Care was also taken to list items not included. For example, the Jamury 1991 Baseline Report is explicit in not inchuding the cost of the land being provided by the State of Texas. As the report points out, the Department has subsequently taken actions to change the method of accounting for project costs. For example, guidance for the preparation of Froject Data Sheets now states that cost estimates include all costs.

Costs for the initial complement of "detectors" (the instruments to be used for scientific experiments) for'a new facility are difficult to estimate at an earty stage of a project. For the SSC, these costs pore irchuded in the baseline, but they were necessily uncertain. The science to be studied and the detector technology were evolving rapidly, and it would have been unwise to fix the dotector designs prematurely. Futhermore, until the SSC project was approved, it.was difficult to ascertiin the foreign contributions of detector systems. As it tumed out, foreign scientific interest was infense and caused the detector scope to expand. For 
such reasons, a phased approach to baselining the cost estimates may be appropriate for similar science projects in the future. Definitive cost estimates for the facility itself should be first established, together with an allowance for the Department's costs for the initial set of dotentors. Only later would the baseline for the scientific instrumentarion be fixed.

The report states that the Department, "...needs to ensure that funding from all sources is secured before thie initiation of a project, "and notes that the failure to secure substitntial foreign fundirig contributed to termination of the project. Finm commitments for all nonFederal (as well as Federai) finds before initiation of a project would certainly be desirable, but such a requirement may not be realistic. Non-Fedieral sources are unlikely to make commitments (especially to a project with the U.S. in the lead role) in the abseice of fim evidence that the project has the suppott and approval of Corgiess. Further, requiring foreign comimitments before starting a project would effectively givie foreign powers a veto over this project.

The report stanes that contract deviations from standard clauses limited the combactor's liability and limited the Department's ability to oversee the project. Indeed, over the years 'bince the SSC contract was signed, such cointracts have been changed to reflect the IG's coneerns as part of the Department's Contract Reform Initiative. However, no conmection is shown in the report linking these comtract deviations to the SSC problems. In fact; the lesson hare secns to be truat these clauses did not result in significant problems for the SSC.

One of the important lessons frotr the SSC is that management of a complex teahtical project in the glare of |publicity is difficult it is not ensy to make necessary, but highly-visible, decisions that may "rock the boat" or to make changes that may appear to show weakmess.

In conclusionj we would note that a balanced approach will be iniportant in applying the lessoris learned from the SSC'to future projects. We should focus on developing a cooperative team spirit needed to get the job done effectively, rather than adding additional layers of staff, systems and regulations. Failure to do-so.is likely to lead to an adversarial relationship with our contractors which will hemper effective accomplishment of the lahoratoxy missions. In spite of departmental efforts to work cooperatively with SSC laboratory management, an adversarigl relationship did develop with the SSC laboratory and contributed to difficulties in the identification and resolution of various project mariagement problems. This may be the most inportant of the lessons to be leanied from the SSC. 
If you have any questions about the conments; please call Robert Diebold on 903-5490, or Myrra Vallette on $903-4476$.

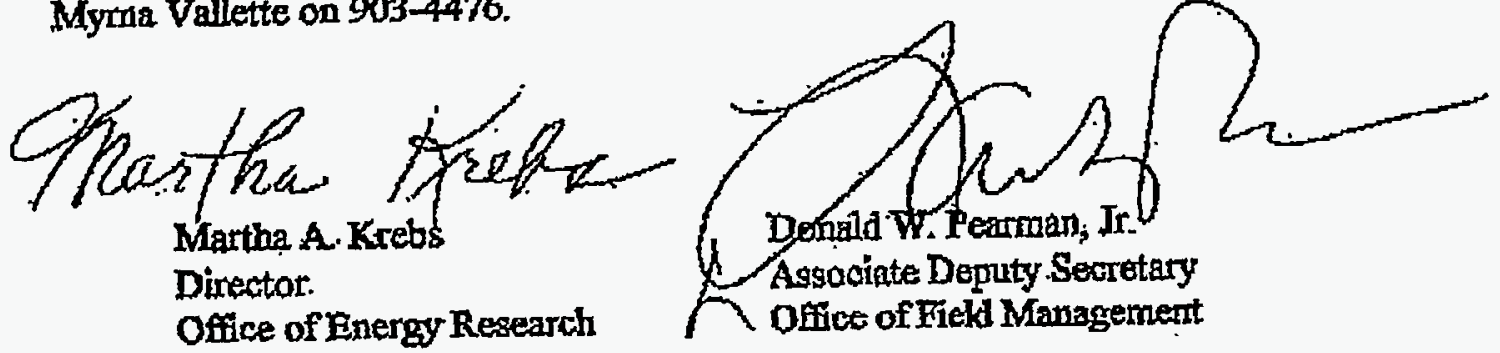


